\title{
Pengaruh Tumpangsari dengan Tanaman Rimpangan Terhadap Infeksi Awal Ganoderma Boninense pada Bibit Kelapa Sawit (Elaeis guineensis)
}

\author{
Rudi Putra Munandar ${ }^{*}$, Suwandi ${ }^{2}$, Suparman $^{2}$ \\ *e-mail : 05012681923006@student.unsri.ac.id \\ ${ }^{1}$ Ilmu Tanaman, Fakultas Pertanian, Universitas Sriwijaya, Indonesia. \\ ${ }^{2}$ Laboratorium Fitopatologi, Program Studi Proteksi Tanaman, Fakultas Pertanian, Universitas \\ Sriwijaya, Indonesia.
}

\begin{abstract}
Basal stem rot (BSR) caused by white decay fungus, Ganoderma boninense is known to cause significant losses in oil palm plantations in Southeast Asia. This study aims determined the effect of oil palm mixed planting with rhizomatous plants, galangal (Alpinia galangal), Java curcumin (Curcuma longa), or ginger (Zingiber officinale) on initial infection of BSR. The research was conducted at screen home October to December 2020. Plants were inoculated by attachment of rubberwood block colonized with $G$. boninense to the main roots. Infection was measured as the length of root necrosis and confirmed by culturing on Ganoderma selective medium. Infection was also assessed by total activity of ligninase as measured by RBBR decolorization. The results showed that $G$. boninense infection at 1-month-post inoculation was lower on a mixed planting with all rhizomatous plants, and the suppression of infection was still occurred in a mixed planting with galangal. The total activity of ligninase on oil palm roots was delayed on a mixed planting compared to that of higher activity on single planting at 1-month-post inoculation. This result highlights the benefit of mixed planting of oil palm with rhizomatous plants in delaying initial infection of BSR pathogen.
\end{abstract}

Key words: oil palm, rhizomatous plants, polyculture, Ganoderma boninense, ligninase

\begin{abstract}
ABSTRAK
Penyakit busuk pangkal batang (BPB) yang disebabkan jamur pelapuk putih Ganoderma boninense menyebabkan kerugian pada perkebunan kelapa sawit di Asia Tenggara. Penelitian bertujuan untuk menguji peranan sistem tanaman polikultur kelapa sawit dengan tanaman rimpangan yaitu lengkuas (Alpinia galangal), temulawak (Curcuma longa), atau jahe (Zingiber officinale) dalam menekan laju penyakit BPB. Penelitian ini dilaksanakan dirumah bayang pada bulan Oktober sampai Desember 2020. Akar bibit kelapa sawit dan rimpangan diinokulasi dengan cara mengikat balok kayu karet yang dikoloni oleh $G$. boninense. Infeksi awal $G$. boninense diukur berdasarkan panjang akar yang mengalami nekrosis dan dikonfirmasi dengan pembiakan pada media selektif Ganoderma. Infeksi juga ditelaah berdasarkan aktifitas total enzim ligninase yang diukur sebagai perubahan warna RBBR. Hasil penelitian menunjukkan bahwa infeksi awal $G$. boninense sampai satu bulan setelah inokulasi menjadi lebih rendah pada sistem tanam polikultur dengan ketiga jenis rimpangan. Sampai 3 bulan setelah inokulasi, penekanan ditemukan pada tumpang sari dengan
\end{abstract}


lengkuas. Aktivitas total ligninase pada akar kelapa sawit menjadi lebih lambat pada sistem polikultur dibandingkan dengan aktivitas ligninase yang tinggi pada monokultur sejak 1 bulan setelah inokulasi. Hasil ini mengindikasikan manfaat polikultur dengan tanaman rimpangan untuk mengurangi laju infeksi awal BPB kelapa sawit.

Kata kunci : kelapa sawit, tanaman rimpangan, polikultur, Ganoderma boninense, ligninase

\section{PENDAHULUAN}

Budidaya tanaman kelapa sawit mengalami banyak masalah salah satunya penyakit busuk pangkal batang (BPB) merupakan penyakit penting tanaman kelapa sawit (Suharyanto et al.,2012). BPB ini disebabkan oleh jamur Ganoderma boninense Pat. yang menjadi ancaman utama pada perkebunan kelapa sawit saat ini di kawasan Asia Tenggara (Breton et al., 2006). Penyakit ini menimbulkan kerugian yang besar pada usaha perkebunan kelapa sawit di Indonesia (Masduki et al., 2003) dan Malaysia (Ommelna et al., 2014). Belum ada pengendalian yang berhasil terhadap penyakit busuk pangkal batang pada kelapa sawit sampai saat ini. Ganoderma spp. memiliki perkembangan yang lambat, tetapi tingkat survivalnya tinggi dan dapat hidup lama sisa tanaman. Potongan bagian tanaman yang terinfeksi sedikit saja bisa menjadi sumber infeksi (Priwiratama dan Susanto, 2020).

Serangan awal BPB sulit untuk dideteksi karena terjadi pada akar dan dalam bonggol. Gejala lanjut atau gejala sekunder adalah perubahan warna daun dan tingkat kecerahan daun atau warna daun memudar (Syahputra dan Agustiaman Purba, 2015). Gejala lanjut adalah munculnya tubuh buah pada pangkal batang ataupun akar. Pada gejala lanjut biasanya tanaman tidak bisa diselamatkan lagi dan harus melakukan eradikasi karena bisa menjadi sumber inokulum (Yanti et al., 2019). Berdasarkan hal ini maka diperlukan penanganan yang khusus dalam pengendalian BPB.
Salah satu cara pengendalian yang potensial dikembangkan adalah dengan memanfaatkan senyawa metabolit sekunder yang berpotensi sebagai pertahanan terhadap patogen (Dalimunthe dan Rachmawan, 2017). Tanaman memiliki metabolit primer yang berperan penting dalam pertumbuhan tanaman dan metabolit sekunder yang sifatnya unik dan terbatas. Eksudat akar, pollen, memecah organ (decomposition), gutasi (volatile) dari daun, batang, merupakan salah satu metabolit sekunder yang dapat dikeluarkan oleh tanaman (Junaedi et al., 2006). Jamur akar putih Rigidoporus microporus dan Ganoderma merupakan jamur dalam ordo yang sama yaitu Polyporales dan juga sama-sama melapuk lignin dan dilaporkan menginfeksi tanaman rimpangan yaitu lengkuas (Suwandi, 2007). Meskipun dapat diinfeksi JAP metabolit sekunder pada tanaman lengkuas dilaporkan dapat menekan pertumbuhan miselium jamur akar putih (Silva et al., 2014). Ganguan pertumbuhan berupa penurunan viabilitas dan pertumbuhan rizomorf jamur akar putih oleh tanaman rimpangan yaitu lengkuas dan temulawak juga dilaporkan oleh Yulianti et al., (2017). Hal ini mengindikasikan bahwa tanaman rimpangan dapat menghambat jamur pelapuk kayu. Tanaman rimpangan menghasilkan metabolit sekunder yang dapat menghambat pertumbuhan miselium cendawan Ganoderma sp. (Rahmadhani et al., 2018) dan dari hasil ini bisa dimanfaatkan untuk menjadi alternatif dalam pengendalian yang lebih efisien dan tahan lama. 


\section{BAHAN DAN METODE}

Pengaruh sistem tanam terhadap infeksi awal $G$. boninense diuji pada 3 sistem tanam tumpangsari antara lengkuas (Alpinia galangal), jahe merah (Zingiber officinale), atau temulawak (Curcuma xanthorrhiza) dengan bibit kelapa sawit di dalam polibeg. Sebagai pembanding digunakan sistem tanam monokultur bibit kelapa sawit. Setiap sistem tanam terdiri dari 5 polibeg sebagai ulangan yang disusun secara acak lengkap (RAL). Penelitian terdiri dari 3 percobaan sistem tanam yang masing-masing terdiri dari 2 perlakuan yaitu kelapa sawit monokultur dan kelapa sawit polikultur.

\section{Inokulum $G$. boninense}

Inokulum patogen disiapkan sebagai balok kayu karet (BKK) yang dikoloni $G$. boninense. BKK ukuran $12 \times 5 \mathrm{~cm}$ dimasukkan dalam kantong plastik tahan panas, ditambahkan $25 \mathrm{ml}$ malt ekstrak, dan diotoklaf dua kali masing-masing selama 120 menit. BKK ditanami 1/4 cawan Petri biakan G. boninense umur 10 hari. Untuk mencegah kontaminasi, sebelum penanaman jamur, BKK disemprot dengan 3\% $\mathrm{H} 2 \mathrm{O} 2$. BKK selanjutnya di-inkubasi tanpa cahaya pada suhu kamar selama 30 hari sampai hifa G.boninense menutupi balok kayu.

\section{Tanaman Uji}

Tanaman rimpangan diperbanyak dari rimpang yang dikumpulkan dari pasar tradisional di Kecamatan Indralaya Utara, Kabupaten Ogan Ilir. Agar diperoleh tanaman yang seragam, rimpang terlebih dahulu ditumbuhkan selama satu bulan. Bibit kelapa sawit uji yaitu $\mathrm{D} \times \mathrm{P}$ Marihat terlebih dahulu disemai selama 2 bulan sampai memiliki 2 daun sempurna. Pada tumpangsari, kedua tanaman pada jarak 10 $\mathrm{cm}$ pada polibeg yang berukuran tinggi 35 $\times 15 \mathrm{~cm}$ yang berisi tanah dan pasir (perbandingan 1:1) sebanyak 5 liter.
Tanaman dipelihara dengan cara disiram setiap hari dan dipupuk mengunakan $0,5 \%$ NPK16-16-16 setiap minggu.

\section{Inokulasi}

Akar yang dinokukasikan yaitu akar primer sebanyak 3 akar primer dalam 1 tanaman yang dikupas tipis dan diukur sama Panjang. Selanjutnya bagian sisi akar yang dilukai, diikat dengan BKK yang dikoloni G.boninense menggunakan parafilm. Akar berikut BKK yang diinokulasi selanjutnya dibenamkan dalam tanah. Setiap satu bulan sampai 3 bulan

\section{Pengamatan Infeksi}

Infeksi awal $G$. boninense pada akar diamati setiap sebulan sekali sampai 3 bulan dengan cara mengukur panjang akar yang mengalami nekrosis (kematian jaringan) dan perubahan warna. Infeksi $G$. boninense pada akar nekrosis dikonfirmasi dengan menumbuhkannya pada medium selektif Ganoderma.

\section{Pengamatan aktivias total ligninase}

Aktifitas total enzim ligninase yang disekresikan $G$. boninense selama proses infeksi awal diukur sebagai perubahan warna RBBR mengikuti prosedur (Machado dan Matheus, 2006). Enzim diekstrak dengan cara menumbuk $1 \mathrm{~g}$ potongan akar dalam 2 $\mathrm{mL} 50 \mathrm{mM}$ buffer natrium asetat $\mathrm{pH}$ 4,6. Filtrat dipipet sebanyak $1 \mathrm{~mL}$ dan disentrifugasi dengan kecepatan $10.000 \mathrm{rpm}$ selama 10 menit. Supernatan enzim kasar dipipet sebanyak $600 \mu \mathrm{L}$ dan disimpan pada freezer sampai digunakan. Aktivitas enzim dimonitor pada $630 \mathrm{~nm}$ mengunakan microplate reader selama 10 menit dari reaksi $600 \mu \mathrm{L}$ ekstrak enzim kasar, $250 \mu \mathrm{L} 50 \mathrm{mM}$ buffer sitrat-fosfat $\mathrm{pH} 4.0,100 \mu \mathrm{L} \quad 0.2 \%$ RBBR, dan $50 \mu \mathrm{L} 2 \mathrm{mM}$ H2O2.

Persentase dekolorisasi dihitung dengan rumus : 


$$
\frac{A-B}{A} \times 100 \%
$$

Absorbansi pada standar $=\mathrm{A}$

Absorbansi pada sampel $=\mathrm{B}$

\section{Analisis Data}

Data panjang akar terinfeksi pada sistem polikultur (tumpangsari) dibandingkan dengan kelapa sawit monokulur menggunakan uji $\mathrm{t}$ dengan terlebih dahulu melakukan uji kehomogenan ragam menggunakan uji Levene. Data aktivitas total ligninase setelah 1, 2, dan 3 bulan inokulasi dibandingkan menggunakan anova dan uji lanjut menggunakan uji BNJ pada taraf 5\%. Analisis data dilakukan menggunakan aplikasi $\mathrm{R}$ versi 4.1 .0 (the $\mathrm{R}$ Foundation for Statitical Computing).

\section{HASIL DAN PEMBAHASAN}

\section{Infeksi akar Tumpangsari dengan tanaman Lengkuas}

Panjang nekrosis akar pada 1 bulan setelah inokulasi pada tanaman sawit monokultur lebih tinggi dari pada tanaman sawit yang ditumpangsarikan dengan tanaman lengkuas, Penanaman polykultur kelapa sawit dengan lengkuas pada 3 bulan lebih rendah secara signifikan akar terinfeksi dibandingkan dengan tanaman sawit monokultur (Gambar 1).

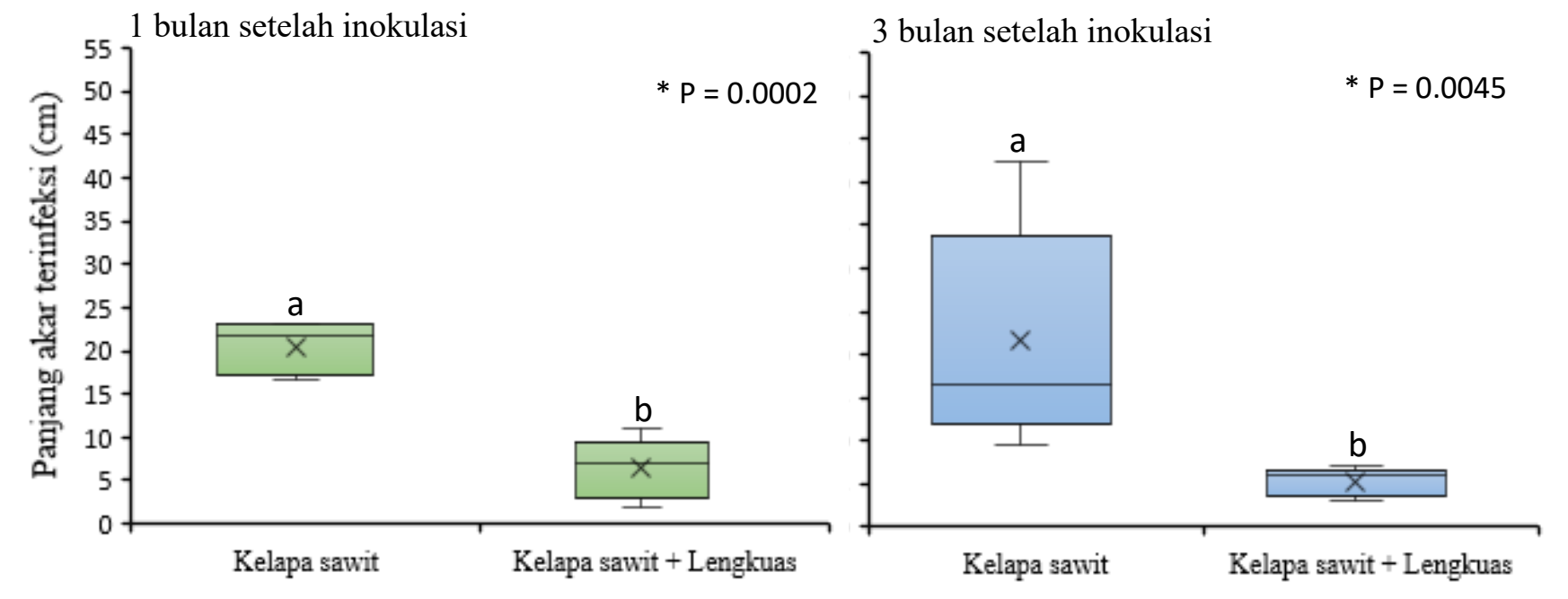

Gambar 1 : Panjang akar kelapa sawit terinfeksi Ganoderma boninense pada sistem kelapa sawit monokultur dibandingkan sistem tumpang sari kelapa sawit dengan lengkuas setelah 1 bulan inokulasi (kiri) dan 3 bulan inokulasi (kanan). (Keterangan : ${ }^{\text {tn }}$ tidak signifikan, * signifikan pada taraf BNJ 5\%)

\section{Tumpangsari dengan tanaman Jahe merah}

Penanaman jahe merah dengan kelapa sawit polykultur menyebabkan nekrosis akar yang secara nyata lebih rendah setelah 1 bulan inokulasi dibandingkan jika kelapa sawit ditanam secara monokultur, Pada saat 3 bulan panjang akar nekrosis pada tanaman sawit monokulkur lebih tinggi dibandingkan pertanaman kelapa sawit polykultur dengan tanaman jahe merah (Gambar 2). 


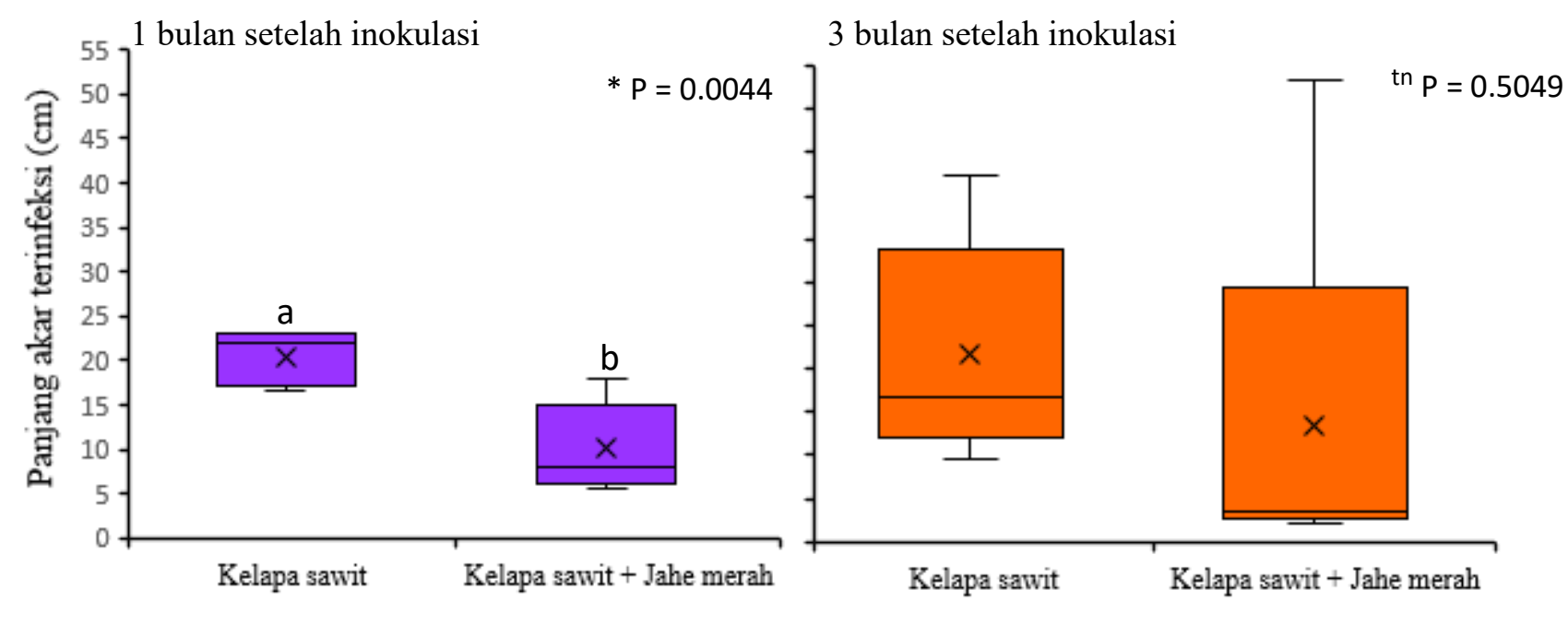

Gambar 2 : Panjang akar kelapa sawit terinfeksi Ganoderma boninense pada sistem kelapa sawit monokultur dibandingkan sistem tumpang sari kelapa sawit dengan jahe merah setelah 1 bulan inokulasi (kiri) dan 3 bulan inokulasi (kanan). (Keterangan : ${ }^{\text {th }}$ tidak signifikan, * signifikan pada taraf BNJ 5\%)

\section{Tumpangsari dengan tanaman temulawak}

Penanaman temulawak bersama kelapa sawit (tumpang sari) menyebabkan nekrosis akar yang secara nyata lebih rendah setelah 1 bulan inokulasi dibandingkan jika kelapa sawit ditanam secara monokultur.
Pada saat 3 bulan inokulasi nekrosis akar kelapa sawit yang ditumpang sarikan dengan temulawak cendrung lebih rendah dari kelapa sawit monokultur meskipun tidak berbeda nyata secara statistic (Gambar 3).
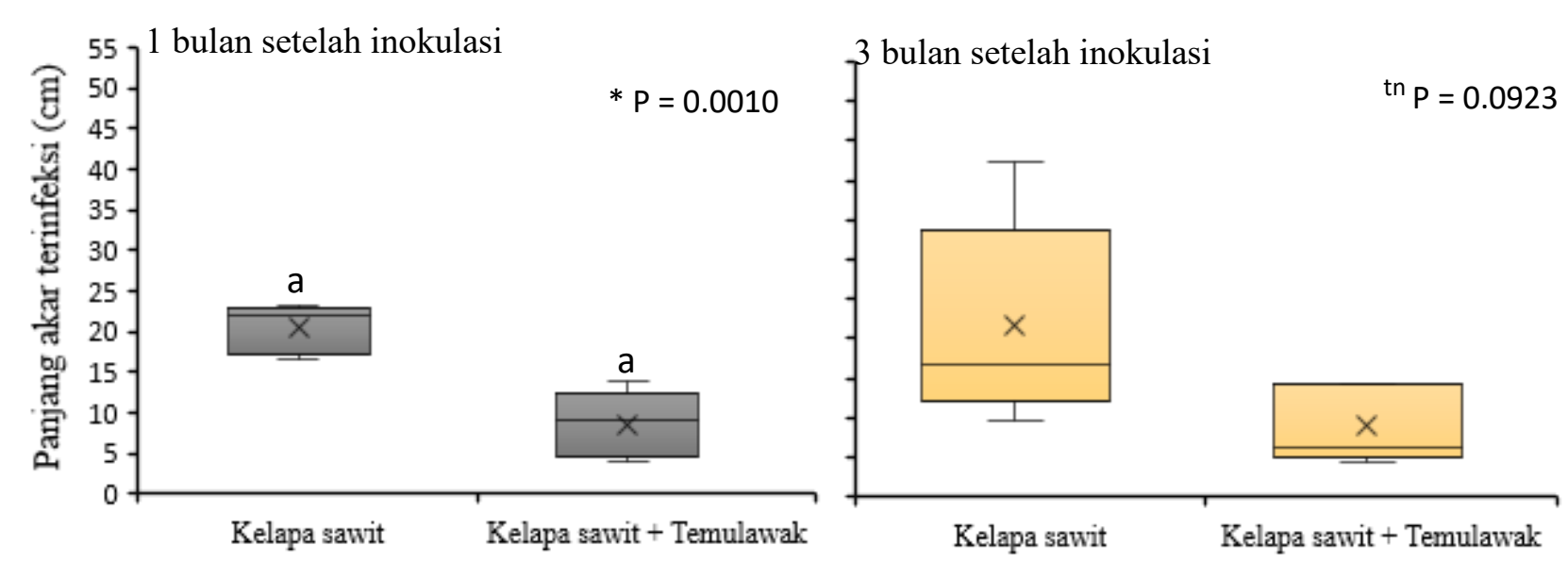

Gambar 3 : Panjang akar kelapa sawit terinfeksi Ganoderma boninense pada sistem kelapa sawit monokultur dibandingkan sistem tumpang sari kelapa sawit dengan temulawak setelah 1 bulan inokulasi (kiri) dan 3 bulan inokulasi (kanan). (Keterangan : ${ }^{\text {tn }}$ tidak signifikan, * signifikan pada taraf BNJ 5\%) 


\section{Dekolorisasi RBBR}

Aktifitas total enzim perombak lignin pada tanaman yang diinokulasi dengan G.boninense diukur sebagai perubahan warna (dekolorisasi) dari biru menjadi ungu atau oranye. Nilai perubahan warna ini diukur intensitasnya pada $\lambda 630 \mathrm{~nm}$. Semakin tinggi persentase dekolorisasi RBBR, semakin tinggi pula aktifitas enzim - enzim perombak lignin (ligninase). Aktifitas ligninase pada akar kelapa sawit monokultur yang diinokulasi G.boninense secara nyata $(\mathrm{P}=$ 0,0085) dipengaruhi oleh waktu setelah inokulasi. Aktivitas ligninase sudah cukup tinggi pada satu bulan setelah inokulasi dan selanjutnya menjadi turun secara signifikan pada bulan kedua dan sedikit meningkat pada bulan ke tiga. Berbeda halnya dengan aktivitas ligninase akar kelapa sawit yang ditumpangsarikan dengan lengkuas yang tidak secara nyata dipengaruhi oleh waktu inokulasi. Akar kelapa sawit tersebut menunjukkan aktifitas ligninase yang rendah pada satu dan dua bulan setelah inokulasi. Setelah 3 bulan inokulasi cenderung terjadi peningkatan aktivitas ligninase meskipun tidak signifikan secara statistik. Sama halnya dengan kelapa sawit, akar lengkuas yang diinokulasi G.boninense juga menunjukkan adanya aktifitas enzim ligninase dengan berubahnya warna RBBR. Respon aktivitas ligninase selama 2 bulan inokulasi pada lengkuas adalah serupa dengan kelapa sawit monokultur, tetapi pada luas terjadi peningkatan aktifitas ligninase yang signifikan setelah 3 bulan inokulasi (Gambar $5)$.

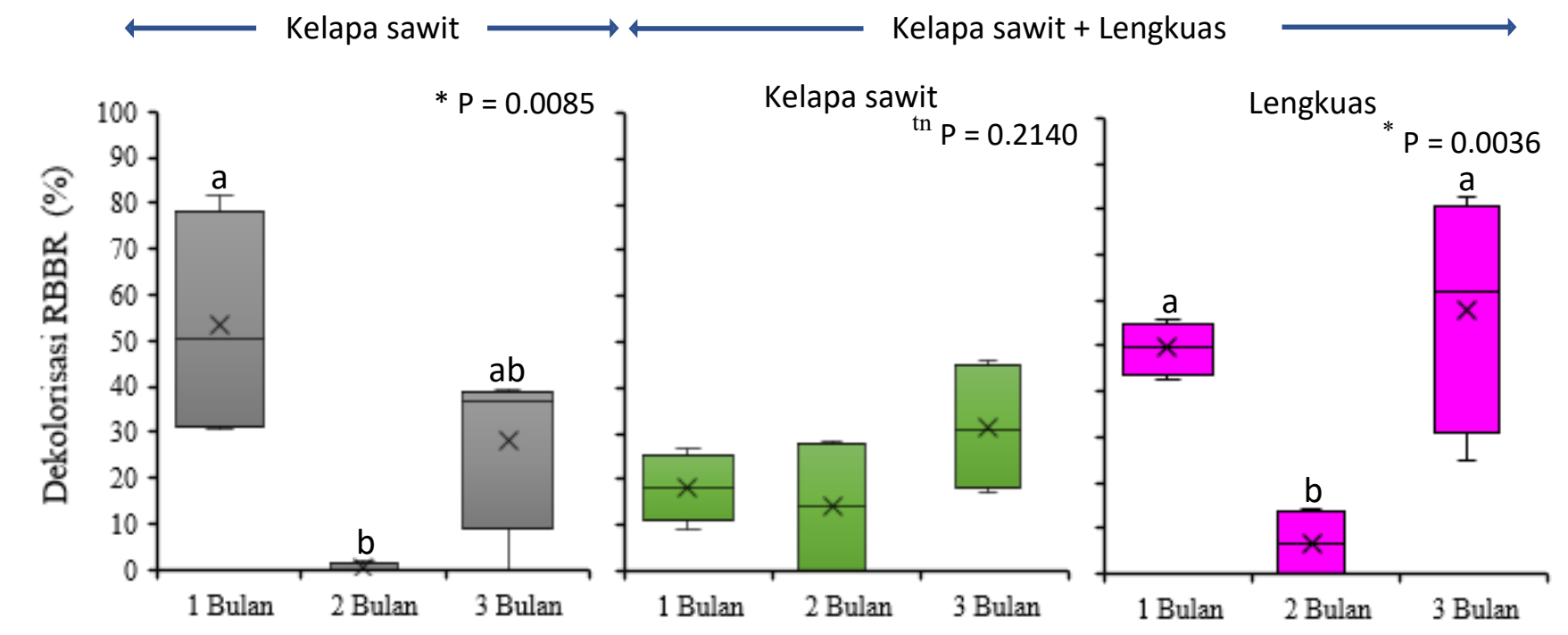

Gambar 4 : Dekolorisasi RBBR (\%) dari akar kelapa sawit pada monokultur (kiri), akar kelapa sawit pada tumpang sari dengan lengkuas (tengah) dan akar lengkuas (kanan) setelah di-inokulasi dengan Ganoderma boninense (Keterangan : th tidak signifikan, * signifikan pada taraf BNJ 5\%)

\section{Tumpangsari dengan tanaman jahe merah}

Aktifitas enzim ligninase pada tanaman kelapa sawit yang ditumpangsarikan dengan jahe merah menunjukkan aktifitas enzim yang rendah pada bulan pertama dan terjadi peningkatan pada bulan kedua dan ketiga setelah inokulasi, tetapi tidak berbeda nyata secara statistik. Berbeda halnya dengan aktivitas ligninase akar jahe merah yang pada awalnya tinggi kemudian sangat bervariasi 
pada bulan kedua dan menjadi rendah aktivitasnya pada bulan ketiga (Gambar 5).

Kelapa sawit

Kelapa sawit + Jahe merah

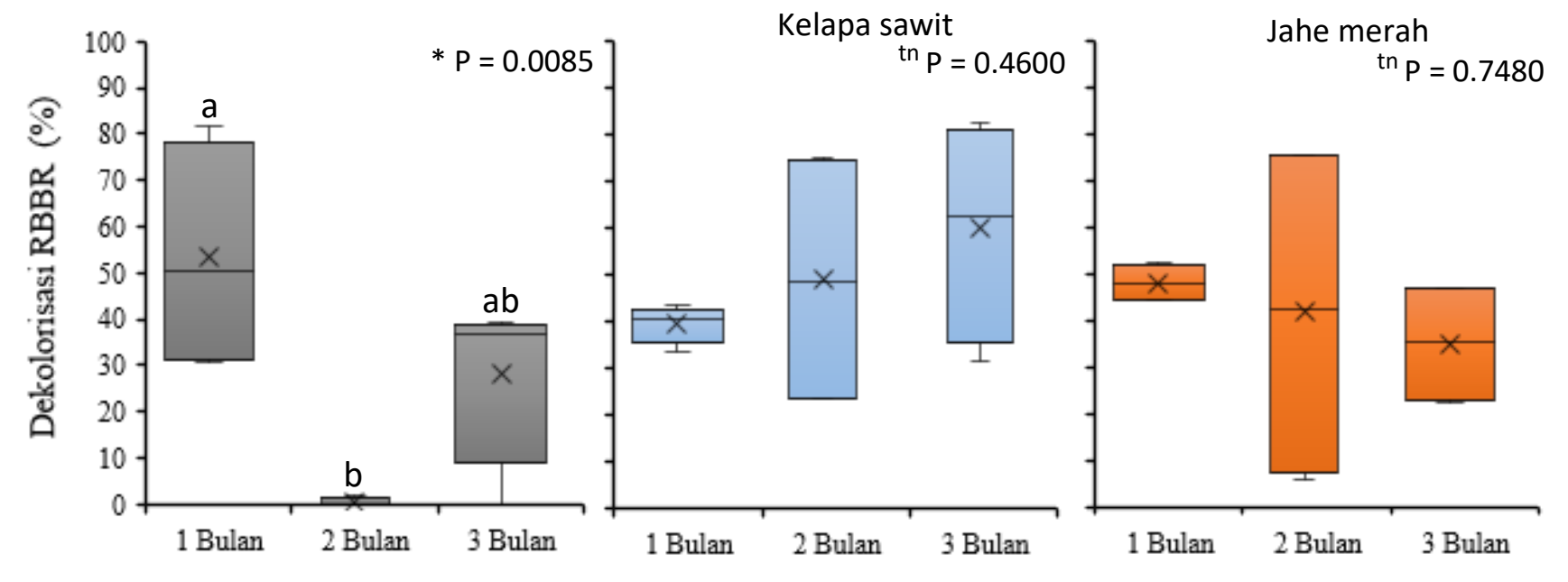

Gambar 5 : Dekolorisasi RBBR (\%) dari akar kelapa sawit pada monokultur (kiri), akar kelapa sawit pada tumpang sari dengan lengkuas (tengah) dan jahe merah (kanan) setelah diinokulasi dengan Ganoderma boninense (Keterangan : ${ }^{\text {tn }}$ tidak signifikan, * signifikan pada taraf BNJ 5\%)

$\begin{array}{cl}\begin{array}{l}\text { Tumpangsari dengan tanaman } \\ \text { Temulawak }\end{array} & \begin{array}{l}\text { tidak terjadi peningkatan pada bulan kedua } \\ \text { dan ketiga setelah inokulasi. Sama halnya }\end{array} \\ \text { Aktifitas enzim ligninase pada } & \begin{array}{l}\text { dengan aktivitas ligninase akar temulawak } \\ \text { tanaman kelapa sawit yang ditumpangsarikan }\end{array} \\ \begin{array}{l}\text { yang pada awalnya rendah pada bulan } \\ \text { dengan temulawak menunjukkan aktifitas } \\ \text { enzim yang rendah pada bulan pertama dan }\end{array} & \begin{array}{l}\text { pertama dan kedua kemudian sangat } \\ \text { bervariasi pada bulan ketiga (Gambar 6). }\end{array}\end{array}$

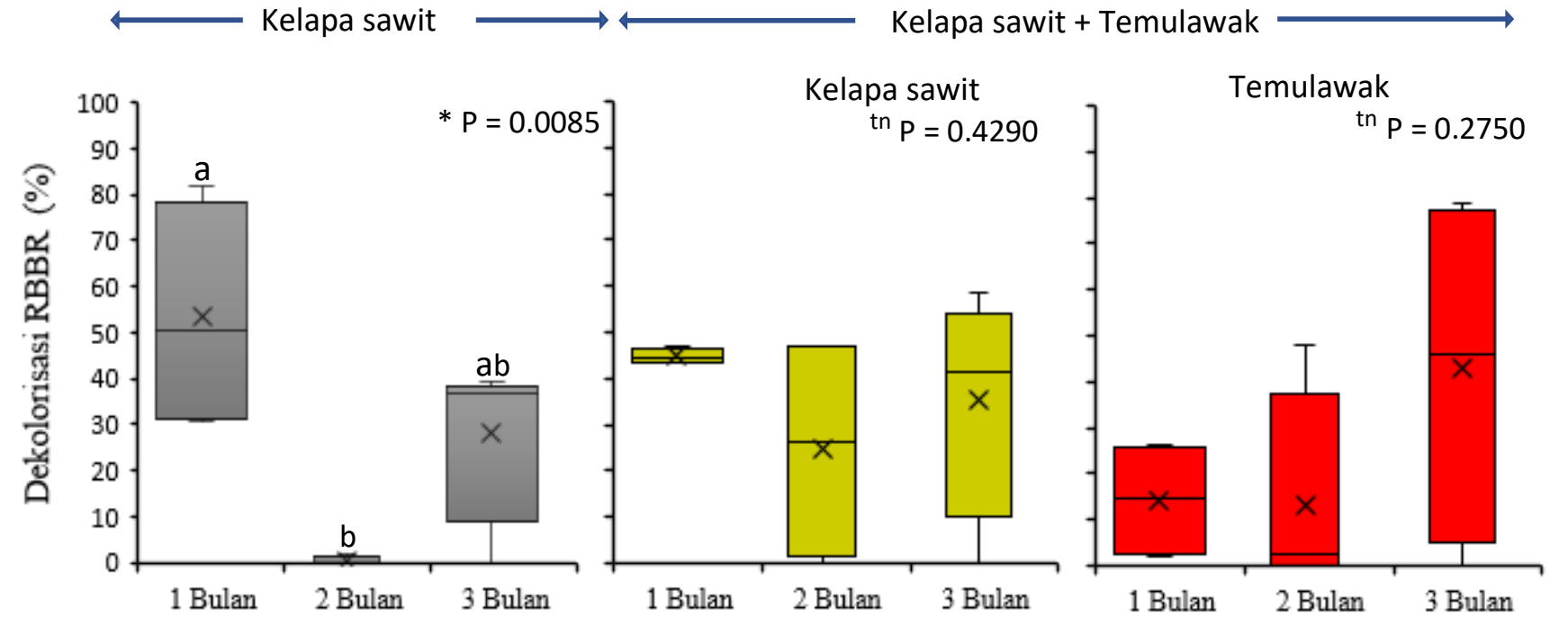

Gambar 6 : Dekolorisasi RBBR (\%) dari akar kelapa sawit pada monokultur (kiri), akar kelapa sawit pada tumpang sari dengan lengkuas (tengah) dan akar temulawak (kanan) setelah 
di-inokulasi dengan Ganoderma boninense. (Keterangan : th tidak signifikan, * signifikan pada taraf BNJ 5\%)

Inokulasi BKK yang dikoloni $G$. boninense menyebabkan nekrosis yang meluas pada akar sejak 1 bulan setelah inokulasi. Setelah 3 bulan perkembangan penyakit bervariasi dan sedikit mengalami peningkatan. Tumpang sari kelapa sawit dengan rimpang-rimpangan menyebabkan infeksi $G$. boninense yang lebih rendah terutama pada fase awal infeksi yaitu 1 bulan setelah inokulasi dikarnakan terdapatnya senyawa metabolit sekunder anti fungi pada tanaman rimpangan seperti pada tanaman lengkuas alkaloid, flavonoid, steroid, dan saponin (Untoro et al., 2016), jahe terdapat alkaloid, flavonid, fenolin, tripenoid (Kaban et al., 2016) dan temulawak ada senyawa Feno, Terpenoid, Saponin, Alkaloid, Tannin (Puspasari et al., 2017). Penekanan penyakit oleh tanaman rimpangan setelah 3 bulan setelah inokulasi terjadi pada tanaman lengkuas. Proses awal infeksi mencakup penetrasi hifa yang diikuti oleh perkembangan dari hifa dan kolonisasi batang bawah dan meluas ke korteks akar melalui sistem vascular. Jamur berperilaku sebagai hemibiotrof yang berkembang secara intraseluler dan belum mengeluarkan enzim ligninase. Fase selanjutnya adalah nekrotrofik yaitu hifa intraselular menyebar membungkus akar yang kemudian baru mengeluarkan enzim ligninase yang melapukkan lignin penyusun kayu (Rees et al., 2009).

Infeksi awal patogen pada akar kelapa sawit yang tinggi pada 1 bulan setelah inokulasi pada penelitian ini dapat dikonfirmasi dari uji aktivitas ligninase yang juga tinggi. Hasil ini sejalan dengan (Goh et al., 2014) yang melaporkan bahwa aktivitas gen penyedia enzim lakkase (golongan enzim ligninase) mencapai pucak aktivitasnya setelah 28 hari inokulasi. Berbeda halnya dengan aktivitasnya pada kelapa sawit monokultur, aktivitas ligninase pada tumpang sari maupun pada tanaman rimpangan berkembang lebih lambat. Hasil ini mendukung aktivitas penekanan infeksi awal pada sistem tumpang sari. $G$. boninense mensekresikan enzim perombak lignin yaitu lakkase dan mangan peroksidase (MnP), dan lignin peroksidase (LiP) yang dilaporkan menentukan tingkat patogenisitasnya (Goh et al., 2014).

Dari ketiga jenis tanaman rimpangan yang ditumpangsarikan dengan bibit kelapa sawit, galangal menunjukkan aktivitas penekanan infeksi awal yang stabil sejak 1 sampai 3 bulan setelah inokulasi. Aktivitas enzim ligninase juga lebih rendah pada akar kelapa sawit yang ditumpangsarikan dengan galangal. Penekanan infeksi awal oleh tumpang sari dengan galangal ini diduga terjadi akibat eksudat akar yang terdapat pada tanaman lengkuas yang menghambat pertumbuhan miselia jamur $G$. boninense (Rahmadhani et al., 2018). Selain mengganggu pertumbuhan miselia G.boninense, ekstrak tanaman galangan dilaporkan bersifat antifungi terhadap white root rot fungus $R$. microporus. Demikianhalnya, ekstrak tanaman jahe merah yang bersifat antifungi terhadap $R$. microporus dimana sifat antifungi ekstrak galangal seperti jahe masih stabil meskipun diberikan ke dalam tanah. Temulawak juga bersifat antifungi terhadap $R$. microporus pada pengujian in vitro, tetapi penghambatan menjadi hilang jika diberikan ke tanah (Silva et al., 2014). Laporan aktivitas antifungi ekstrak rimpang lengkuas, jahe, dan temulawak telah dilaporkan di mana-mana diantaranya terhadap Colletotrichum spp. patogen kedelai (Yulianti et al, 2017), ekstrak rimpang jahe merah terhadap Pythium sp. pada tanaman mentimun (Mujim, 2010), ekstrak lengkuas dan jahe merah yang secara in vitro mampu menekan patogen antraknosa tanaman pisang (Puspa et al., 2015). Hasil penelitian ini mendemonstrasi tentang 
potensi polikultur dengan tanaman rimpangan untuk mengurangi laju infeksi awal dalam pengendalian BPB kelapa sawit. Polikultur dengan tanaman rimpangan dapat dijadikan sumber penghasilan sampingan dalam budidaya tanaman kelapa sawit.

\section{KESIMPULAN}

Bibit kelapa sawit yang ditumpangsarikan dengan tanaman rimpangan menyebabkan infeksi awal yang lebih rendah dibandingkan bibit kelapa sawit monokultur dibuktikan dengan nekrosis akar dan aktivitas ligninase yang lebih rendah. Infeksi paling rendah ditemukan pada sistem polikultur dengan tanaman lengkuas.

\section{UCAPAN TERIMA KASIH}

Penelitian didanai skim Penelitian Dasar Unggulan Perguruan Tinggi dengan Kontrak Penelitian Nomor: 150/SP2H/LT/ DRPM/2021 yang diketuai oleh Dr. Suwandi.

\section{DAFTAR PUSTAKA}

Breton, F., Hasan, Y., Lubis, Z., dan Franqueville, H. De. (2006). Characterization of Parameters for the Development of an Early Screening Test for Basal Stem Rot Tolerance in Oil Palm Progenies. Journal of Oil Palm Research, (106), 24-36.

Dalimunthe, cici indriani, dan Rachmawan, A. (2017). Prospek Pemanfaatan Metabolit Sekunder Tumbuhan sebagai Pestisida Nabati untuk Pengendalian Patogen pada Tanaman Karet The. Warta Perkaretan, 36(1), 15-28.

Goh, K. M., Ganeson, M., dan Supramaniam, C. (2014). Infection potential of vegetative incompatible Ganoderma boninense isolates with known ligninolytic enzyme production. African Journal of Biotechnology, 13(February). https://doi.org/10.5897/AJB2013.13409

Junaedi, A., Chozin, M. A., dan Kim, K. H. O.
(2006). Perkembangan Terkini Kajian Alelopati. Hayati Journal of Biosciences, 13(2), 79-84. https://doi.org/10.1016/S19783019(16)30386-2

Kaban, alpina nora, Daniel, dan Saleh, C. (2016). Uji Fitokimia, Toksisitas dan Aktivitas Antioksidan Fraksi N-Heksan dan Etil Asetat terhadap Ekstrak Jahe Merah (Zingiber officinale var. amaru. Jurnal Kimia Mulawarman, 14, 24-28.

Machado, katia maria gomes, dan Matheus, D. R. (2006). Biodegradation of Remazol Brilliant Blue $R$ by Ligninolytic Enzymatic Complex Produced by Pleurotus Ostreatus. Braziilian Journal of Microbiology, 468473.

Masduki, A., Haska, N., dan Mikawa, T. (2003). Molecular Identification and Characterization of Ganoderma boninense. Jurnalis Ilmu Kefarmasian Indonesia, 1.

Mujim, S. (2010). Pengaruh Ekstrak Rimpang Jahe (Zingiber officinale Rosc.) terhadap Pertumbuhan Pythium Sp. Penyebab Penyakit Rebah Kecambah Mentimun Secara In Vitro. J. Hpt Tropika, 10(1), 5963.

Ommelna, Jennifer, dan Chong, K. . (2014). The potential of chitosan in suppressing Ganoderma boninense infection in oil palm seedlings. Journal of Sustainability Sciense and Management, 7(December 2012), 186192.

Priwiratama, H., dan Susanto, A. (2020). Kejadian Penyakit Busuk Pangkal Batang pada Tanaman Sistem Lubang Tanam Standar. Warta PPKS, 25(3), 115-122.

Puspa, T., Efri, Y., dan Prasetyo, J. (2015). Pengaruh ekstrak beberapa tanaman famili zingiberaceae terhadap penyakit antraknosa pada buah pisang. j.Agrotek Tropika, 3(2), 231-235.

Puspasari, L. D., Azizah, N., dan Nihayati, E. (2017). Studi Ekstrak Rimpang Temulawak (Curcuma xanthorriza Roxb.) pada Perkecambahan Kedelai (Glycine max). Jurnal Produksi Tanaman, 5(1), 150-153.

Rahmadhani, T. P., Pujiastuti, Y., dan Suwandi. (2018). Growth Response of Ganoderma sp. Mycelium Treated with Root Exudates of Herbaceous Plants Tiara. Biovalentia, 
4(1), 1-4.

Rees, R. W., Flood, J., Hasan, Y., Potter, U., dan Cooper, R. M. (2009). Basal stem rot of oil palm ( Elaeis guineensis ); mode of root infection and lower stem invasion by Ganoderma boninense, 982-989. https://doi.org/10.1111/j.13653059.2009.02100.x

Silva, M. K. R., Jayasinghe, C. K., dan Tennakoon, B. I. (2014). Evaluation of the antagonistic effect of different plant species on white root disease causing fungus: Rigidoporus microporus. Journal of the Rubber Research Institute of Sri Langka, 25-32, 25-32.

Suharyanto, Eris, deden sewantara, Prakoso, haryo tejo, Saragih, A., dan Darmono, T. (2012). Perangkat serologi untuk deteksi dini infeksi Ganoderma sp . pada kelapa sawit. Menara Perkebunan, 80(1), 8-16.

Suwandi. (2007). Mode of Dispersal nnd Variation In Population of White Root Fungus Rigidoporus microporus as Revealed by Mycelial Incompatibility. Indonesian Rubber Research Institute International Rubber Research And Development Board, 68-75.

Syahputra, I., dan Agustiaman Purba. (2015). Benih Kelapa Sawit (Elaeis guineensis
Jacq.) Dxp Socfindo Mt Gano Moderat Tahan Ganoderma boninense. Jurnal Pertanian Tropik, 2(3), 264-274.

Untoro, M., Fachriyah, E., dan Kusrini, D. (2016). Jurnal Kimia Sains dan Aplikasi Isolasi dan Identifikasi Senyawa Golongan Alkaloid dari Rimpang Lengkuas Merah (Alpinia purpurata). Jurnal Kimia Sains Dan Aplikasi, 19(2), 58-62.

Yanti, Y., Rifai, I., dan Arnetti. (2019). Penapisan Isolat Rizobakteri indigenos untuk Pengendalian Ganoderma boninense pada Bibit Kelapa Sawit ( Elaeis guineensis Jacq .). Jurnal AIP, 7(2), 59-68.

Yulianti, S., Suwandi, dan Nurhayati. (2017). Kemampuan Tumbuhan Terna dalam Menekan Potensi Inokulum Rigidoporus microporus Suppression Ability of Herbaceous Plants on Inoculum Potential of Rigidoporus microporus. Jurnal Fitopatologi Indonesia, 13, 81-88. https://doi.org/10.14692/jfi.13.3.81 